\title{
Naif Sanat ve Safranbolulu Naif Ressam Recai Demirsöz'ün Sanat Anlayışı
}

\author{
Anil Ertok Atmaca* \\ Karabük Üniversitesi, Güzel Sanatlar Fakültesi, Karabük.
}

\begin{abstract}
$\ddot{O} z$
Naif resim, Fransızca "naive" kelimesinden dilimize yerleşmiştir. Saf ve yapmacıksız anlamına gelmekle birlikte genellikle eğitim görmemiş sanatçlar ve çalışmaları için kullanılmaktadır. Herhangi bir kuramsal çerçevenin içinde değildir. Çoğu kez çocuksu bir betimlemeyi tanımlar. Bireysel içgüdülere ve sezgilere dayanmaktadır. 19. yüzyılda başlayan ve 20. Yüzyılda yayılmış olan Naif sanat, ülkemizde 1950'li yıllarda hareket kazanmıştır. Naif sanatın bir tür veya akım olarak ortaya çıması ile birlikte sanat piyasası da bu yönde bir devinim kazanmıştır. Naif sanata yönelme özellikle 20. Yüzyıl Fransız sanatında belirgin olarak görülmektedir. Picasso, Gauguin gibi sanatçllarm halk sanatlarma yönelimleri ve bunun sonucunda çocuksu saflı̆̆ı arayış çabaları bunun en belirgin örnekleridir. Bununla birlikte dünyada bilenen en önemli temsilcisi Henri Rousseau 'dur. Naif sanatın Türkiye'deki temsilcilerine örnek olarak Fahir Aksoy, İbrahim Balaban, Mehmet Pesen, Hikmet Karabucak, Oya Katoğlu gibi sanatçllar verilebilir. Naif resmin günümüz Türk sanatında da temsilcileri bulunmaktadır, zaman zaman kişisel, zaman zaman da grup sergileri açarak kendilerini ve eserlerini sanat izleyicisine sunarak sanat ortamında yerlerini alırlar, bu sanatçlardan birisi de araştırmamızın konusunu olan Safranbolulu Naif ressam Recai Demirsöz'dür. Makalede Naif sanatın kısa bir tanımlaması verilerek araştırmamanın evrenini teşkil eden Naif ressam Recai Demirsöz'ün sanat hayatına ve eserlerine yer verilmiştir.
\end{abstract}

Anahtar Kelimeler: Sanat, Naif, Primitif, Recai Demirsöz

\section{Naive Art and the Sense of Art of Artist Recai Demirsöz from Safranbolu}

\section{Abstract}

Naive painting was settled into our language from "naive" which is a french word. Besides having the meaning "Pure and unaffected", it is also used for uneducated artists and their works. It is not any theoritical framework. It often defines a childish description. It is based on individual instincts and intuitions. Naive art starting in 19th century and expanding in 20th century gathered movement and speed in 1950s. With the emergence of naive art as a species or a movement,art market has gained momentum in this direction. Inclining on naive art is prominently seen especially in 20th century French art. Tendencies and efforts of seeking childlike purity of the artists like Picasso and Gauguin are the most significant samples of this and besides, the most important representative of naive painting is Henri Rousseau. Some of the representatives of naive painting in Turkey are Fahir Aksoy, İbrahim Balaban, Mehmet Pesen, Hikmet Karabucak and Oya Katoğlu. Today there are representatives of naive painting in our country, they take place in art environments through holding their group exhibitions and exhibiting their works for the art audience and one of the artists is Naive Artist Recai Demirsöz from Safranbolu. The art life and works of Naive artist Recai Demirsöz forming the nature of the study have been included in the essay.

Key Words: Art, Naive, Primitive, Recai Demirsöz 


\section{Giriş}

Safranbolu tarihi dokusu ve içinde barındırdığı zenginlikleri ile burada yaşayan ve inceleyen araştırmacılar için bir hazine niteliğindedir. Uzmanlığınız ne olursa olsun zengin bir tarihe sahip olduğu için derinliklerinde pek çok bilgi ve tecrübeyi yaşayabileceğiniz bir atmosferi bu şehirde bulabilirsiniz. Mimari ve tarih'e olan yakınlığı ile bu iki alan için muhteşem bir zemin olmakla birlikte Safranbolu'nun sanat anlamında da köşelerinde bulunabilecek birçok sürprizler vardır. Tarihini soluduğunuz her evin içinden geleneksel el sanatlarına dair örnekleri bulabileceğiniz gibi şehir hayatı içinde günümüz sanatına dair hareketleri de kolayca elde edebilirsiniz. Şehri inceledikçe yüzyıllardır sanatı seven bir halkın içinde yaşadığınızı fark edebilirsiniz. Sanat, var olduğu toplumlarda yerleştikçe devamlığını sağlar, Safranbolu'da bunun pek çok örneği görülebilir örneğin; el sanatları açısından sayıları az da olsa mesleklerini icra eden köşe başında küçük dükkânlar size geçmişin bir görüntüsünü sunabilir. Halk sanatlarının sayıları az da olsa bazı örnekleri Safranbolu'da görülebilmektedir.

Sanata bu kadar yakın bir şehir de müzik, sinema ve araştırmamızın konumuzu teşkil eden plastik sanatlar ile ilgili pek çok faaliyet yaşanmaktadır. Karabük ve ilçesi konumundaki Safranbolu'da gerek devlet kurumları gerekse özel kamu kuruluşlarının sanata yakın destekleri gözlenmektedir. Bu noktada pek çok sanatsever çalışmalarını sürdüğü gibi birçok sergi de sık aralıklara açılmaktadır. Güzel Sanatlar Fakültesine sahip şehirde Karabük Üniversitesi de bu anlamda sanatçı adayı da yetiştirilerek bu sürece destek vermektedir.

Akademik anlamda sanatçı yetiştiren ve kamu kurulularının açmış olduğu sanat kurslarının yanı sıra şehrin içinde yetişen eğitim almamış Halk Sanatını icra eden ya da Naif diye tanımladığımız sanatçılar da bulunmaktadır, bunlardan birisi Recai Demirsöz'dür. Araştırmamızın ana evrenini Türkiye'de Naif Sanat, Naif sanatçı Recai Demirsöz'ün sanat hayatı ve bu güne kadar üretmiş olduğu eserlerin görsel dili oluşturmaktadır.

\section{Naif Sanat ve Türk Naifleri}

Naif resim Fransızca "naive" kelimesinde dilimize yerleşmiştir. "Saf ve yapmacıksı" anlamına gelmekle birlikte genellikle eğitim görmemiş sanatçılar ve çalışmaları için kullanılmaktadır. Herhangi bir kuramsal çerçevenin içinde değildir. Çocuksu bir betimlemeyi tanımlar çoğu kez. Bireysel içgüdülere ve sezgilere dayanmaktadır.

Naif ressamlarca geliştirilen teknik ve üsluplar, hemen daima kişisel niteliktedir. Bunlarda çoğu kez büyük bir ayrıntı zenginliği gözlenir. Dış gerçekliği akademikleşmiş yanılsama teknikleriyle değil de adeta "masum bir gözle" algılayıp betimlemeleri açısından sanatsal değer taşırlar (Söze ve Tanyeli, 2012: 219). Naif sanatın ne zaman ortaya çıtığına dair aslında tam bir tarih verilemez gibi çünkü sanatın var olduğu zamandan beri yapılan pek çok sanatsal çalışma bir noktada halk 
sanatı kapsamında naif olarak tanımlanabilir bununla birlikte naif sanatın akım ve kavram olarak tartışıldığ

17-19. yüzyıllarda yazında ( edebiyatta) söyleyiş biçimi için, şiirde ayrıntı için, bazen olumlu bazen olumsuz olarak kullanılmıştır. Schiller'e göre "naif şiir doğal olan, nesneye bakılarak yazılandır. Doğa, sanat ve ideal üç aşamadır ve üç aşama, naif, santimantal, ve sentetik şiirle özdeştirler. 1970'lerde Ankara Dil Tarih ve Coğrafya Fakültesinin tiyatro bölümünde Prof. Meinecke, Prof Melahat Özgü, Prof. Özdemir Nutku Türk seyirlik oyunlarından kukla, karagöz ve orta oyunu üzerinde incelemeler yaparak naif sanatla ilintilerini ve öğelerini araştırmışlardır. Bu sözcügün görsel sanatlar alanına bir deyim olarak geçişi 19. Yüzyılın sonlarına doğru, soyut sanatın Dünyaya yayıldığı döneme rastlar ve Henri Rousseau ile başlar (Aksoy, 1990: 5). Fovizm ve Kübizm ile birlikte I. Dünya savaşından önce Montmarte'da doğan ve Guillaume Apollinaire gibi şairlerin de desteğini gören bir başka cereyanın "naif resmin" rayına oturması ve bütünüyle kabullenilmesi savaş sonrasına rastlar (Aksoy, 1990: 27).

Sanatın en safını, salt sanata en yakın olanı tanımlamak amacıyla "naif" sanata; daha sonra ise bunun da yetmediğini düşünenlerce türetilen değişik terimlere yönelinmiştir. Örneğin, Dubufet'nin "İşlenmemiş Sanat" anlamına gelen "Art Brut" terimi, kültür tarafından niteliği henüz bozulmamış anlamında kullanılmıştır. Sanatçılar, akıl hastanelerinde veya dışarıda, eğitsel, kültürel ve geleneksel etkilerden arınmış bir ortamda yaşamaktadırlar. Ona göre art brut, görsel yaratımı en saf şekli, ruhsal bir içtepinin beyinden kâğıda akışıdır. Art brut kadar yaygın olmasa da başka terimler de kullanılmış, bunlar hakkında kitaplar yazılmış, hatta müzeler bile açılmıştır(American Visionary Art Museum). “Neuve Invention” (Yeni Buluş), art brut kategorisine uymakla birlikte, bu terimin tanımının sınırları Dubuffet tarafından kısıtlandığı için, dünyayla daha fazla ilişkisi olan sanatçıların ürünleri için ayrılmıştır (Manukyan, 1999: 40).

Naif sanat ile ilgili Doğu Avrupa ülkelerinde de ciddi çalışmalar yapılmış, Okullar açılmış, sempozyum düzenlenmiştir. Çekoslavakya'nın Bratislava kentinde İnsita dergisi çerçevesinde toplanıp her üç yılda bir sergiler düzenleyen kurumun ve Çek düşünürlerin özellikle Stefan Tcack'ın ortaya attığ "insite" deyimi ve bu sanata yeni bir tanım getirilmesi önerisini içeren bildiri, sanat çevrelerinde büyük yankılar uyandırmıştır ve bu toplantılar birbirini izlemiştir. Amaç çağdaş sanatsal anlatım çerçevesi içinde bu sanat dalına kendisine yaraşır bir yer sağlamaktı. "İnsite" sözcük olarak Latinceden üretilmiş olup, yalın, saf, yapmacıksız, anlamına gelmektedir (Aksoy, 1990: 33).

Tüm çabalara rağmen, bu terimin birkaç ülke dışında kullanımı pek yaygın değildir. İçten gelen bir dürtüyle veya Tanrı'nın çağrısına uyularak yapılan her türlü yapıt için kullanılan "Visionary/Intuitive Art" (Sezgisel Sanat) terimleri daha geniş kapsamlı olmakla birlikte sınırları kesin değildir (Manukyan, 1999: 41).

Naif sanatın oluşumu, sanat tartışmaları ve dönünüşümlerin yaşandığı yıllara rastlar. Bu yıllarda ilkel ve geleneksel sanatlara karşı yönelimler belirginleşmiştir. 
Primitivizm/İlkelcilik olarak adlandırılan yeni bir etkilenim alanı ortaya çıkmıştır. Halk sanatları ile önce Japon tahta oymalarına, sonra Afrika'nın güney denizlerindeki adaların ve Amerika kabilelerinin sanatlarına karşı belirginleşen ilgi, batılı sanatçıların kalıplaşmış bazı anlayışları sorgulamalarına yol açmış, onlara yeni çalışma alanları oluşturmuştur. Dönemin en ilkelci sanatçılarından biri olan Gauguin akademik anlayışa karşı çıkarak ilkellerin yaşamını ve sanatını incelemeye başlamıştır (Lynton, 1991).

Günümüzde her türlü çanak çömlek, mücevherat, ev eşyası ya da giyim, gerçekleştirilmeden önce kâğıt üzerine tasarlanmaktadır, primitif toplumlardaysa, malzeme sanatçının ellerinde, parmakları arasında yaratıyordu. Onlar biçim vermenin kendisinden müthiş bir haz alarak yaratılıyorlardı. Mutlak bir özgünlük, ayrıca gücün ve yaşamın yoğun ve çoğu zaman da grotesk biçimlerinin sade bir şekilde ifade bulması bizlerin bu yerli sanatlardan hoşlanmamızın nedeni belki de budur (Nolde, 1912; aktaran Antmen, 2010: 42).

Naif sanat ve Primitif sanat sıkça birbirine karıştırılmakla beraber, benzer yönleri ve çağdaş olmalarının yanında kesinlikle aynı değildirler. 20. Yüzyılın başında Matisse, Derain, Picasso, Vlaminck Afrika mask ve sanatını keşfettikleri dönemde modern sanata uyarlamaları ile primitif sanatın örneklerini uygulamışlardır. Afrika masklarının ilk önce sanatçının bulduğuna dair pek çok yorum bulunmakla beraber ilk keşfedenin Vlaminck olduğuna dair yorumlar da vardır. Primitif sanatın belki de en ünlü yorumlarını Picasso da görebiliriz.

Modern sanatçıların "primitif"in önündeki eğilişi, Batılı olmayan kültürleri daha mutlu, daha doğal, daha az bilgili ve daha az namussuz olarak idealleştiren Avrupa düşünce geleneğinin bir parçası olarak görülebilir. Övgü taşısa da, özellikle modern sanatçıların çocuklar, deliler ve eğitimsiz "naif" yetişkinler tarafından üretilen sanatın "primitivizm"ini de alkışladıkları düşünülürse bu, aynı zamanda aşağılayıcı bir basitleştirmedir. "Primitivizm" geniş biçimiyle özellikle Ortaçağ ahşap oymaları ve Gotik oymaları gibi Batı sanatı içinde üretilen ifadeci, akademik olmayan sanatı da kapsar (Little, 2013: 103).

Naif sanat ise genellikle çocuksu bir saflık içinde resmedilir, sanatçları ise genellikle sanat eğitimi almamış kişilerdir dünyada en çok tanınan temsilcisi Gümrükçü Rousseau'dur, Picasso'nun çağdaşı olan ressam, o dönemde Picasso gibi birçok sanatçının takdirini kazanmıştır (Franck, 2009: 116-123).

Nihayetinde Naif sanat, 20. Yüzyılın başından itibaren halk sanatlarından bağımsız olarak ele alınmaya başlanmıştır. Akademi dışı faaliyetler olarak beliren bu anlayış, zamanla çocukların, akıl hastalarının ve köylü ressamların eserlerinin de bu grup içinde ele alınmasını gerekli kılmıştır. Rousseau ve arkadaşlarından oluşan "Saf Yürekler" grubu, 1920 ve 30'larda daha geniş bir coğrafyada kendilerini var etmişler, naif sanatın modern sanat akımları içinde yer almasını sağlamışlardır.Yoksulların, akıl hastalarının ve çocukların yaptığı sanatsal faaliyetler, II. Dünya Savaşı sonrasında Dubuffet öncülüğünde "Art Brut" adı altında değerlenirilmeye başlandığından bahsetmiştik. Bu tarihlerden itibaren çok sayıda amatör ressam ortaya çıkmıştır. 
1950'lerden itibaren naif ve otodidakt sanat/sanatçılarla ilgili yayınlar ve etkinlikler artarak sürmüştür (Elvan, 2001: 23). II. Dünya Savaşı sonrasında dünyada olduğu gibi bizde de modern sanatın önemsemediği naif / otodidakt yapıtlara, çocuk yaratıcılığına duyulan merak, akademi dışı oluşumlar; karşı duruşlar önem kazanırken 'soyut sanat', 'halk sanatı', 'köylü sanatı' benzeri konular biçimci / formalist değerlendirmelerin dışarıda tuttuğu 'ötekilere duyulan ilgiyi artırmıştır. Bu noktada "Otodidakt" terimi Naif sanat ile birlikte kullanılmaktadır, Otodidakt, Öğretim kelimelerinden türemiştir Düşünerek, derinleşerek, hazmederek odaklı öğrenme şekli. Herhangi bir okula, eğitim sistemine bağlı olmaksızın kendi başına yapılan düşünmelerle, araştırmalarla, tartışmalarla, çalışmalarla öğrenme halidir, otodidaktizm ilk kez 1160'larda Endülüs'lü filozof Abu Baker İbn-Tufayl'in felsefi romanı Hayy'de bahsedilmiştir. Marakeş"li vahşi bir çocuğun kendi kendine çeşitli aletler geliştirerek doğayla mücadelesinin anlatıldığı hikâyede "insanı geliştiren toplum ya da onun sözleşmeleri değil, kendisidir" vurgusu dikkat çekmektedir. Odak noktadaki yaklaşım; "insan en yalın bilgidir" olmaktadır. Tarihten bilinen en önemli otodidaktlardan biri Leonardo da Vinci'dir (Tarhan, 2013). Terim benzerliği nedeniyle Naif sanatçılara çoğu kez Otodidakt da denmektedir.

Erken 20. yüzyılın kübizm, fütürizm, konstrüktivizm gibi sanat akımlarının geçmişin dramatik olgularından, kültürel kodlamalarından uzaklaşan ve hatta daha da ileri giderek hazır haldeki nesnelerin varoluşundaki anlamı yeniden bağlamlandırarak 'ressamca' resimleme tekniklerini anlamsızlaştıran Marcel Duchamp gibi Dadaist yaklaşımların görmezden geldiği bu dışarıda bırakılmış sanat olgusu, II. Dünya Savaşı ve sonrasında değer kazanmıştır. Savaş ve sonrasının modernizm krizi, modern sanat dışındaki sanatsal yaratımın anlamının, varlıksal gücünün ve 'sanat yapma İsteği'nin bir uğraş olarak işlevselliğinin yeniden gözden geçirilmesini sağlar. 20. yüzyılın ortalarında 'öteki' gelenek ve kültürlerdeki yaratıcılığın, düş gücünün önemsenmesi, ilkel toplumların, çocukların, akademik eğitim almamış kişilerin modern dışı yaratımlarının değerlendirilmesi, saf aklın ürettiği biricik / özgün yapıt karşısında naif sanatçının 'taklit' etme, gerçeği kavrama ve benzetme isteğindeki 'farklılıkta saklı yaratıcılı̆̆ın görmezden gelinemeyeceğine işaret etmiştir (Yasa Yaman, 2008).

Naif sanatın kuralsızlıkları ya da belli bir kuramın içinde olmadığından bahsetmiştik, çünkü naif ressamlar bireysel ve kendi evrenleri içinden yola çıkarak duygusal resimler yapmaktadırlar. Bununla birlikte kendiliğinden oluşan bir ortak dile sahip olduklarından da söz edebiliriz.

Yvon Dagle, 23 madde de naif sanat özelliklerini sıralamıştır. Bunların arasında gözleriyle değil, kalbiyle çizme, kendisi için resim yapma; mutlulukla, neşeyle, oyun gibi yapma; gölgeye fazla önem vermeme; iki boyutta ve yassı mekanda kendini gösterme; renk teorilerini hiçe sayma gibi maddeler yer almaktadır (Manukyan, 1999: 41). İçü̈düsel ve spontane olması, parlak renk kullanımı, detaylı anlatım ve basık, düz mekan anlayışı olarak belirlenebilir. Naif resimlerde kompozisyon boşluk bırakmama endişesiyle doldurulur. Nesneler en belirgin özellikleri vurgulanarak anlatılır. Bir bütünü oluşturan bütün parçalar tek tek ele alınır. Genellikle tam profilden ya da tam cepheden resimlenen figürlerde göz, kaş ya da saç gibi belirgin özellikler abartılarak 
verilir. Bu abartmalar mizahi etkiler yaratır. Kullandıkları perspektif ve ritm duygusu yeni ve özgündür. Perspektif kullanımındaki farklılıklar figürleri, nesneleri "havada asılı kalmış ya da yüzüyormuş gibi" gösterir. Hareketler donmuştur (Chilvers, Osborn ve Farr, 1998: 360; Atkins, 1990: 46; Erzen, 1997: 1331-1332 aktaran Elvan, 2001: 21).

Naif sanatın taşıdığı tüm özellikleri ile dünyada ortaya çıkışının 19. Yüzyıl olduğunu bilmekteyiz. Özellikle Avrupa'da birçok örneği ile ciddi bir sanat tarzı olarak ele alınmıştır. Bununla birlikte Türkiye'de naif sanatın ilgi odağı olması gecikmiştir, ama geleneği eskidir. Cumhuriyet öncesinde bile halk sanatı adı altında birçok yapıta imza atmış sanatçılar vardır. Tuval üzerine yapılmış olmayanlar dahi, resim sanatının başarılı örnekleri arasında yer alırlar (Manukyan, 1999: 41).

Cumhuriyet'in ilk yıllarında ve onu izleyen 1950'lere kadarki süreç içinde, bir ulusal sanat yaratma çabası vardır. Müzikte çokseslilik, plastik sanatlarda yerel değerlere yönelik ilgiler, Cemal Tollu'yu Hitit sanatına, Turgut Zaim'i bir oranda halk sanatına, B. Rahmi Eyüboğlu'nu yine halk sanatına bağlamıştır. Nurullah Berk'in minyatür düzeninden ulusal sanata uzanma çabaları Sabri Berkel tarafından desteklenmiştir (Koçan, 1999: 39).

1950'lerde sanat hayatında belirli değişiklikler gözlenir bunlara; sosyoekonomik yapının liberalleşmesi çabalarına paralel olarak sanatsal davranışlar ve üslup değerlerinin bireysel özellikler kazanması, resimsel temaların seçiminde sanatçıların iç dünyaları ve kişisel yaşantılarına ilişkin gerçekleri ön plana almaları. Dıştaki doğal ve toplumsal çevrenin resim diline aktarılmasında öznel yorum haklarının serbestçe kullanılmaya başlanması, resim alanında evrensel değerler savı karşısında, yerel-ulusal kültürlere ilişkin değerler sorununun güçlenerek gündemde kalması gibi nedenler sayılabilir(Tansuğ, 1995: 12).

Daha öncesinde Naif sanat ile birlikte sıkça kullanılan "halk sanatı" adı altında değerlendirilebilecek çalışmalar akademili sanatçılar tarafından yapılmıştır. Bunlara Bedri Rahmi Eyüpoğlu, Nedim Günsür, Mehmet Pesen, Turgut Zaim, Berna Türemen, Cihat Burak gibi isimler, bunun yanında eğitim almamış olan Naif sanatçılara Fahir Aksoy, İbrahim Balaban, Oya Katoğlu, Aziz Alpagut, Uğural Gafuroğlu, Nihal Siralar, Yusuf Karabıyık, gibi sanatçllar örnek verilebilir.

Türkiye'de Hırvatistan'da olduğu gibi naif sanatçı yetiştirmek amacıyla bir okul kurulmamıştır, ancak Osmanlı ve halk sanatının çok zengin mirasından etkilenen sanatçıların yapıtları benzer özellikler göstermektedir. Çoğunda bir mutluluk ve iyimserlik havası sezilmektedir. Üzüntü, korku veya endişe gibi değişik duygulara fazla rastlanmamaktadır. Belli konuların dışına da çıkılmamaktadır. Bunun yanı sıra, Türkiye'de birlikte sergileyen bir grup oluşmuştur. Yaklaşık otuz kişilik bir grup, yılda bir kez karma sergi düzenleyerek yapıtlarından örnekler sunmuşlardır. İstanbul'daki bu sergilerden seçmeler Ankara ve İzmir' de de sergilenmiştir(Manukyan, 1999: 45). 


\section{Naif Ressam Recai Demirsöz ve Sanat Anlayışı}

Ressam Recai Demirsöz, 31 Ocak 1956 yılında Safranbolu'nun Üçbölük köyünde doğmuştur. Tarihi eskilere dayanan köyün ilk adı Ilbarıt olmakla birlikte sonradan değiştirilmiştir. Naif ressam 1962 yılında başladığı ilkokulu, bazı yıllar köye öğretmen gelmemesi nedeniyle 1968-69 yılında bitirir. Bu dönem içinde 6 kadar Öğretmenin değiştiğinden bahseder. Ressam için eğitim almak o dönemlerde köy ortamında oldukça zor olmuştur. Bu olumsuzlukların içinde Recai Demirsöz için en iyi eğitim babasından aldığı eğitim olur. Ressam, babasının eğitimli olmamasına rağmen ileri görüşlü ve aydın bir kişi olduğundan bahseder, Sokrates, Homeros, Herodot gibi düşünürleri babası sayesinde küçük yaşlarda tanımıştır. Hikâyeler ile oğluna yeni bir dünya yaratan babası aynı zamanda müziğe olan merakını oğluna da aşılamıştır.

Kendisi ile yaptığımız röportajda ressam, hayatının bundan sonraki sürecini şöyle anlatır: "İlkokul bittiğinde ailemizin maddi durumu iyi olmaması yüzünden diğer okulları okuma şansım olmadr.1970-71 yillarında İstanbul'da halamlarm yanında ortaokula başlasam da, halamlar" bizim durumumuz da iyi değil" diyerek okutamayacaklarım söylediler. Okuldan o yıl ayrılıp İstanbul'da daha küçük denilecek yaşta çalışmaya başladım. O yıllarda da resimlere önem verdim. Resim yapmaya fazla firsatım olmadı̆̆ iç̧in, artık sürekli okuyordum. Illk önce dünya insanlığını daha net tanımam için dünya klasiklerini okumaya başladım, daha sonralar felsefeye yöneldim. Beni etkileyen felsefecilerin başında kitapları olmasa da Sokrates öğrencisi Platon gelir ve Bertnard Russel, Kant ve Friedrich Nietzcehe gibi felsefecilerin yanında, Rus edebiyatının öncüleri sayılan Dostoyevseki, Tolstoy, Gogol ve Gorki'dir. Gorki benim gibi firın işçiliği yaptığından en idolümdür."

1969'dan itibaren 1980 yılına kadar İstanbul da yaşayan Recai Demirsöz, o yıl köyüne geri döner ve halen de burada yaşamaktadır. Yağlı boya resme geçmeden önce desen çalışır, daha sonraları köyünde resim yapmaya başlamıştır. İstanbul da çalıştığı süreçte sergileri gezme imkânı bulan Recai Demirsöz, yağlı boya resimler ile orada tanıştığından bahseder. Galeri sahibine bu tarz resimlerin nasıl yapıldığına dair sorular soran ressam, daha sonra aldığı bilgiler ile yağlıboya çalışmalarına başlar.

Recai Demirsöz ile yaptığımız röportajda anlattığı gibi yaşamında kendisine verilenle yetinmemiş ve öz çabaları ile bilgi ve deneyimlerini geliştirmeye çalışan bir kişilik çizmektedir. Evinde yaptığımız görüşmede bunun izlerini kolayca görmekteydik, duvarlara asılı yüzlerce kâğıtta birçok ünlü düşünür, ressam, yazarlardan anekdotlar bulunuyordu, ressam zaman zaman sohbet esnasinda bu yazılardan bir kısmını kullanmaktaydı. Evinde bulunan kitaplardan da okumaya ve araştırmaya kendini adamış bir sanatsever olarak kendisini ispatlamaktaydı.

Recai Demirsöz 30 yıldır resim yapmaktadır ve çalışmalarından bazıları Safranbolu Kaymakamlığı tarafından açılan köyde bulunan Sanat Galerisinde sergilenmektedir. Bu Galeri şair Şükrü Erbaş’ın girişimleri ile dönemin Kaymakamı Celal Ulusoy'u arayarak Recai Demirsöz'ün varlığından bahsetmesi sonucu başlayan süreçte 1999 yılında açılmıştır. 
Resimlerinden bazıları bu galeride, binanın yan tarafında bulunan çalışma ofisinde ve bir kısmı da evinde bulunmaktadır. Resimlerinin sayısı net olarak kendisi de bilmemekle birlikte 100 civarlarında olduğu tahmin edilmiştir. Çalışmalarını evinin içindeki boş bir odada saklayan ressam bunların birçoğunu tavandan sarkıtarak korumaktadır. Bir bölümü yerde olan çalışmalarını belli bir düzen içinde sıralamıştır, kendisine bu çalışmaların nasıl koruduğunu sorduğumuzda Picasso'dan bir örnek verir: "Picasso çok üreten bir sanatçı olması nedeniyle çalışmalarımı korumakta da zorlanmıştır ve tozlanan resimleri için toz resmin örtüsüdür demiştir ben de öyle düşünüyorum" demektedir.

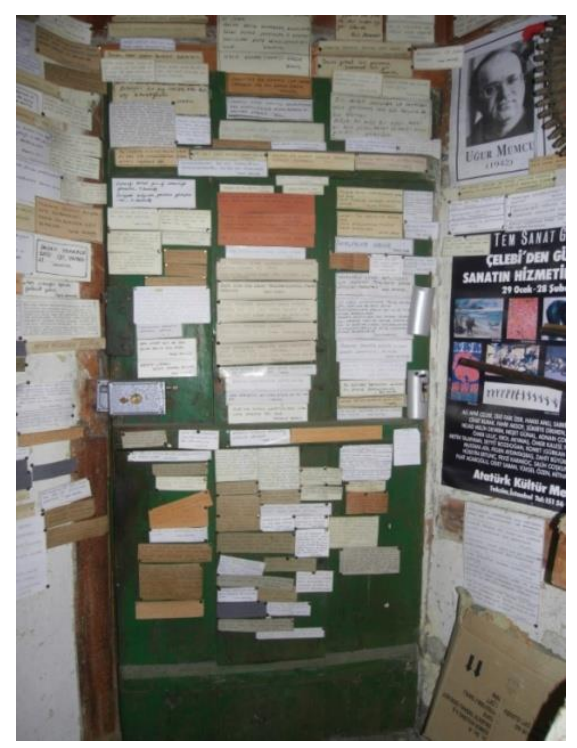

Fotoğraf 1: Ressamın evinden detay

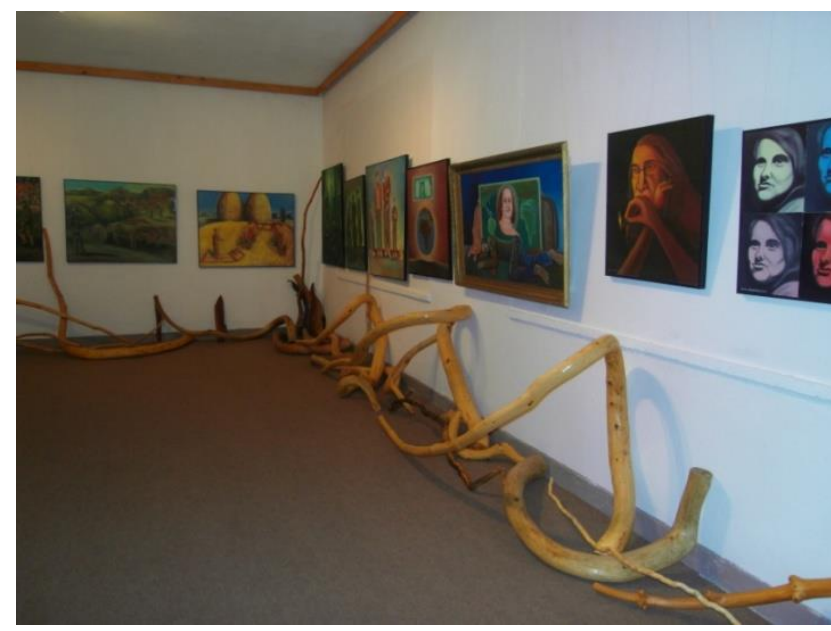

Fotoğraf 2: Galeriden detay

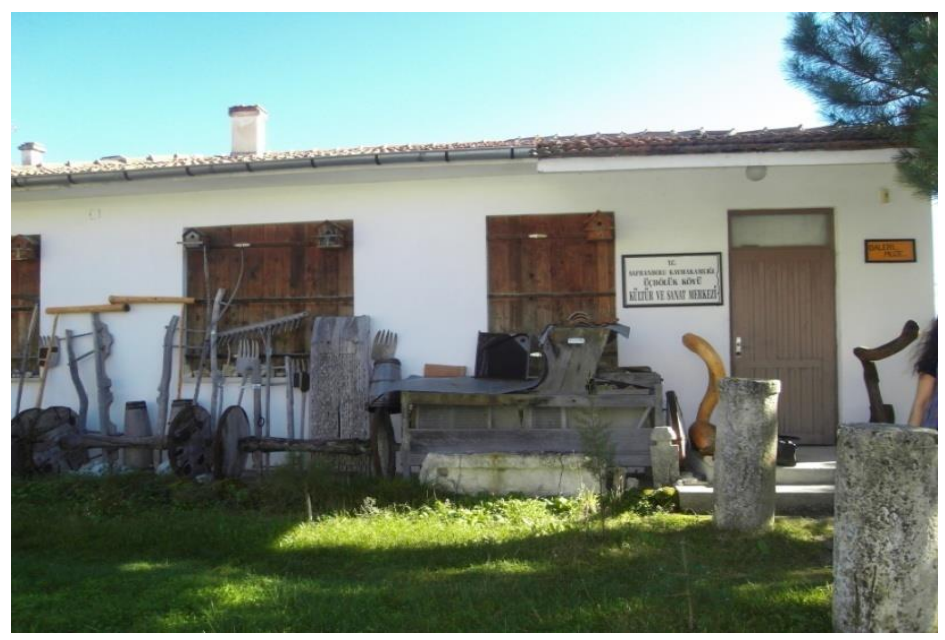

Fotoğraf 3: Galerinin dış bölümü

Naif sanatçının görülebilen eserlerinde yıllar içinde değişen teknik ve konular dikkati çekmektedir. Resim yapmaya başladığı ilk yıllarda desen araştırmaları yapmak için çıplak kadın figürlerini resmettiğini anlatır, bunlar hayalden çalışılmış figürlerdir, 
ressam ayrıca kadınları resmetmekteki başka bir amacını da Picasso'nun sözleriyle açıklar " kadın acı çeken bir makinedir". Recai Demirsöz'e göre tanıdığı pek çok kadın acı çekmektedir, bundan etkilenen naif ressam kadınlara bu açıdan bakarak resmeder. Yıllar içinde konuları ve tekniği değişime uğramış bu çalışmaların hepsi Naif sanatın saklı kalmış örneklerindendir.

Köylü ressamlar sınıfına da giren Recai Demirsöz'ün çok az köy temalı resimleri bulunmaktadır. Yaşadığı köyde böyle bir imkân bulamadığı için köy resimleri yapmadığını, galeride bulunan birkaç köy resmini de galeri bahçesinde bulunan tarım aletlerinin ne işe yaradığına dair gelen sorular neticesinde bunu göstermek amaçlı yaptığını anlatmaktadır. (Resim1, 2)

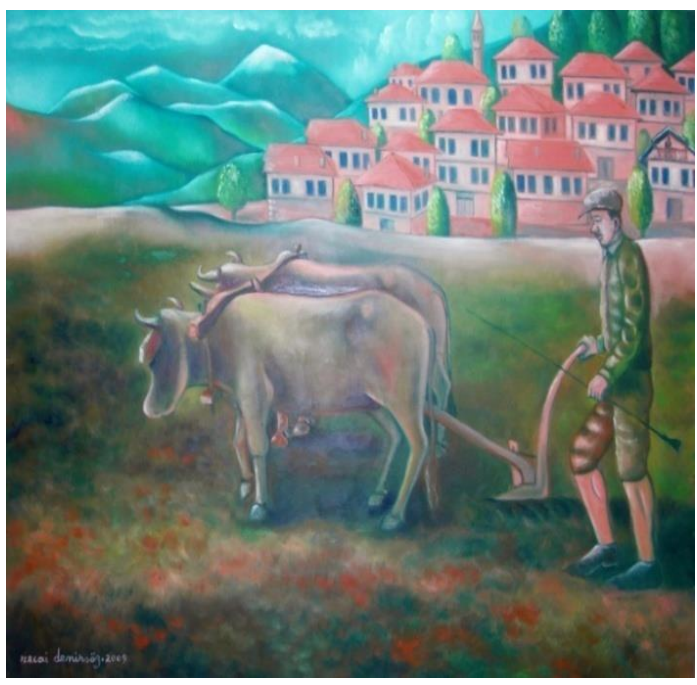

Resim 1

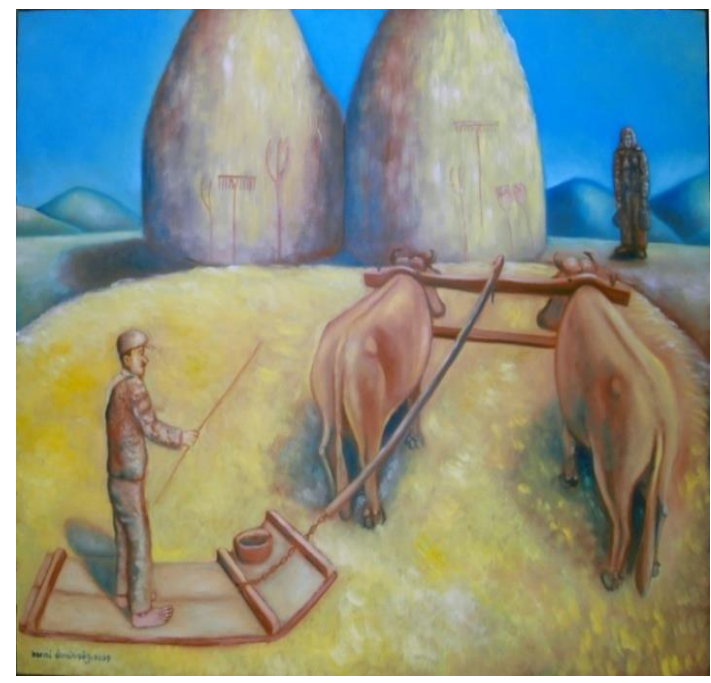

Resim 2

Recai Demirsöz'ün çalışmaları figüratif olarak gerçekçi bir anlayışla resmedilmeye çalışılmıştır. Figürlerde kasıtlı deformasyonlar ve abartılar zaman zaman karşımıza çıkmaktadır, yakın çevresinden kişileri olduğu kadar sanatçının hayranlık duyduğu kişilerin de portreleri galeri içinde görülebilir (resim3, 4) . Resim 3’te görülen yaşlı erkek figürü sanatçının babasıdır. Röportajlar esnasında sıkça bahsi geçen babasının da sanatçı bir ruha sahip olduğunu öğreniyoruz, müzik aleti yapabilen babası aynı zamanda bu aletleri çalabilmektedir, sanatçı bu çalışmasında babasının yapmış olduğu ve çalabildiği müzik aletleri ile birlikte bir kompozisyon kurmuştur. Kompozisyonun merkezinde babası bulunur, figür gülmez adeta müzik aletlerine odaklanmamızı ister gibi ciddiyetle bize bakmaktadır. Bu çalışmada kullanılan renkler açısından sanatçının soğuk renkleri tercih ettiğini görüyoruz. Ressam, görüşmemizde gri renklerden oluşan bir çalışma yapmak istediğinden bahseder, "neden?" diye sorduğumuzda Andre Gide'in ünlü sözünü hatırlatır bize: "Gerçekler gridir." Toplumsal gerçekçi Neşet Günal'ın çalışmalarını da takdir eden Recai Demirsöz'ün bu çalışmasında Neşet Günal'ı hatırlatan etkiler bulunmaktadır. Resim 4'de ise yine bir portre çalışması olarak Halk müziği sanatçısı Ruhi Su ve Ünlü şair Nazım Hikmet Ran'1 görmekteyiz, çalışmada ileri doğru bakan iki figür geleceği gösterir gibidirler. Ruhi Su'nun elinde sıkıca tuttuğu saz vurgulanarak sanatçının saz ile olan ilişkisini 
vurgulamak ister gibidir. Figürlerin her ikisinde de vücutlarının tamamlanmadığını görmekteyiz, ressam burada kompozisyonun bütünlüğü açısından endişe taşıdığı ve yarım bırakarak bütünlük sağlamak istediği anlamı çıkarılabilir. Çalışmasında bakışlara ve saza odaklanılmasını istemiş gibidir.

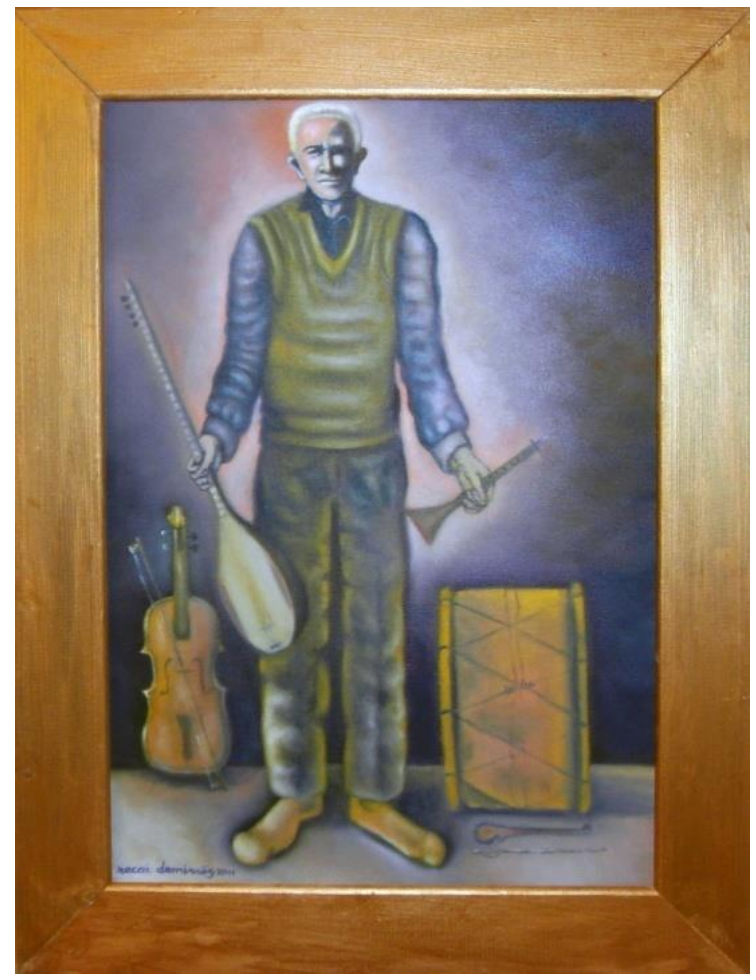

Resim 3

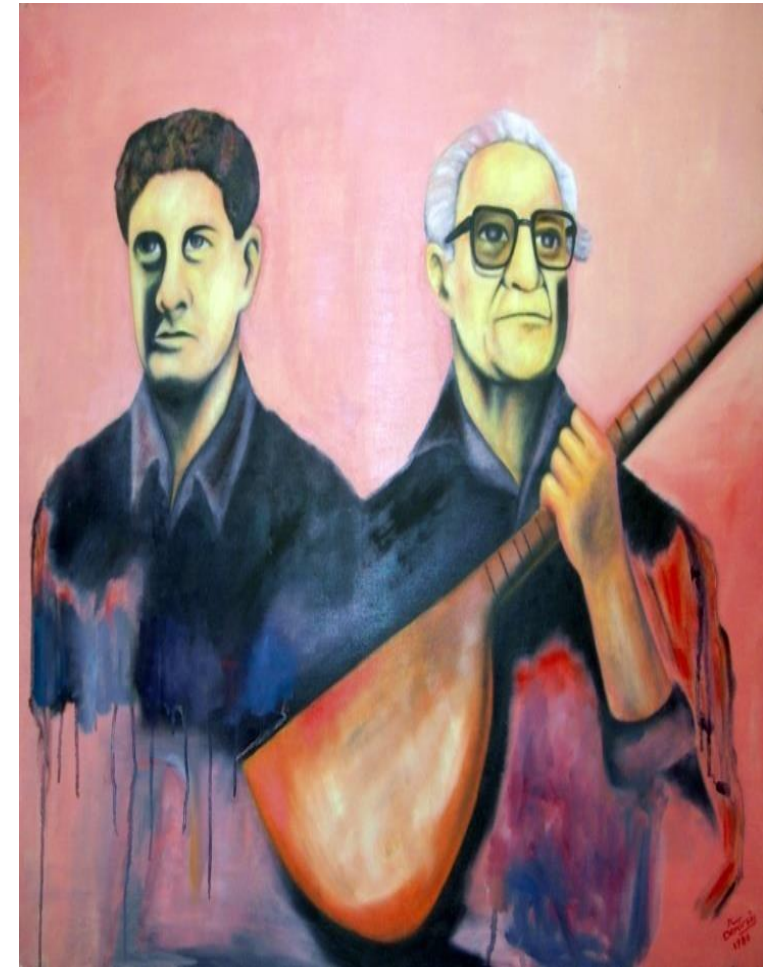

$\operatorname{Resim} 4$

Demirsöz'ün genel anlamda resimleri ağırlıklı olarak sosyal konulardan oluşmaktadır. Sanatçı yaşadığı coğrafyanın dışında, dünyada yaşanan sosyal olaylara ve felaketlere duyarlı davranmaktadır ve çalışmalarının büyük bir kısmını bu noktalara değinerek resmeder. Kazancının büyük bölümünü okumaya ayıran Recai Demirsöz, bir dünya insanı olarak karşımıza çıkmaktadır. Resimlerinde Türkiye'de yaşanan olayların yanında kapitalizm, emperyalizm ve kaynakların tüketimi, küreselleşme gibi pek çok konuya değinmektedir. 


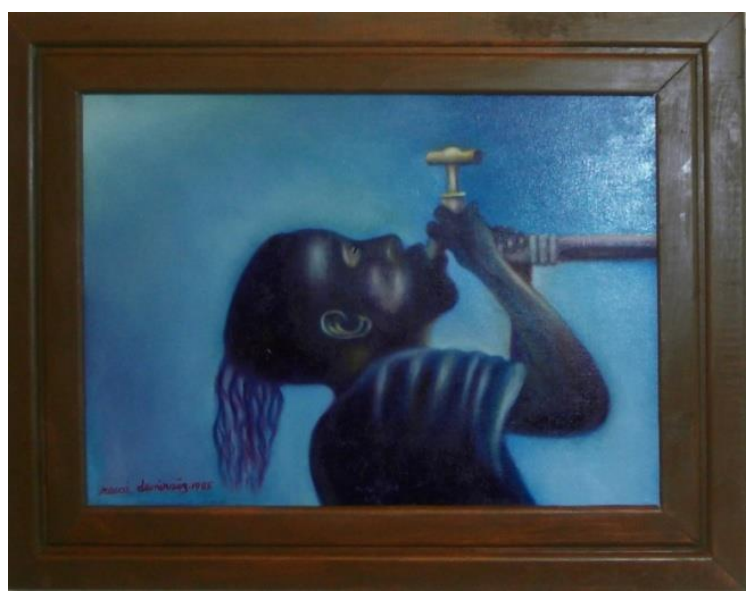

Resim 5

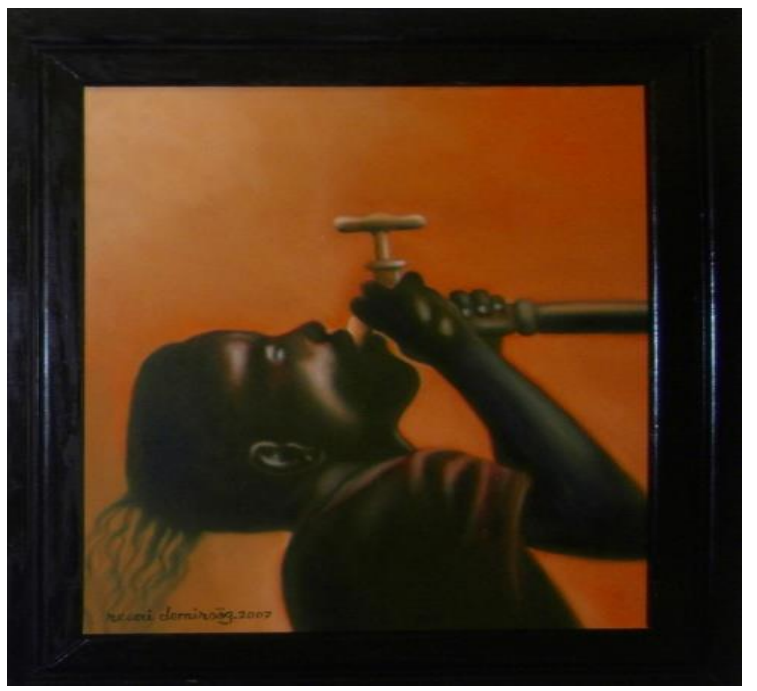

Resim 6

Resim 5 ve resim 6, sanatçının evrensel konulara duyduğu alakanın bir göstergesi olan resimlerden ikisidir, her iki çalışma da konu açısından aynıdır, ayrılan yönleri renkler ve tuval boyutu olarak dikkati çekmektedir. Resim 5, 1980 yılında yapılmış olup esin kaynağ 1 Cumhuriyet Gazetesine ait Siyaset Dergisinde gördüğü bir fotoğraftır, konusu Afrika'da o dönem başlayan susuzluk sıkıntısıdır. Ressam o dönem gördüğü fotoğraftan oldukça etkilendiği için bu çalışmayı yaptığını anlatır. 1990 yılında o gün etkilendiği susuzluk sorunun Türkiye'de de ortaya çıkmasıyla bu konuya bir kez daha vurgu yapmak ister ve bu kez kırmızı rengin hâkimiyetiyle ikinci çalışmasını yapar, bu resimde kırmızı hâkimiyetini fark ederiz, sanatçının anlatımına göre kırmızı burada susuzluk problemi hakkında Türkiye için de tehlike çanlarının çaldığını belirtmek içindir. 


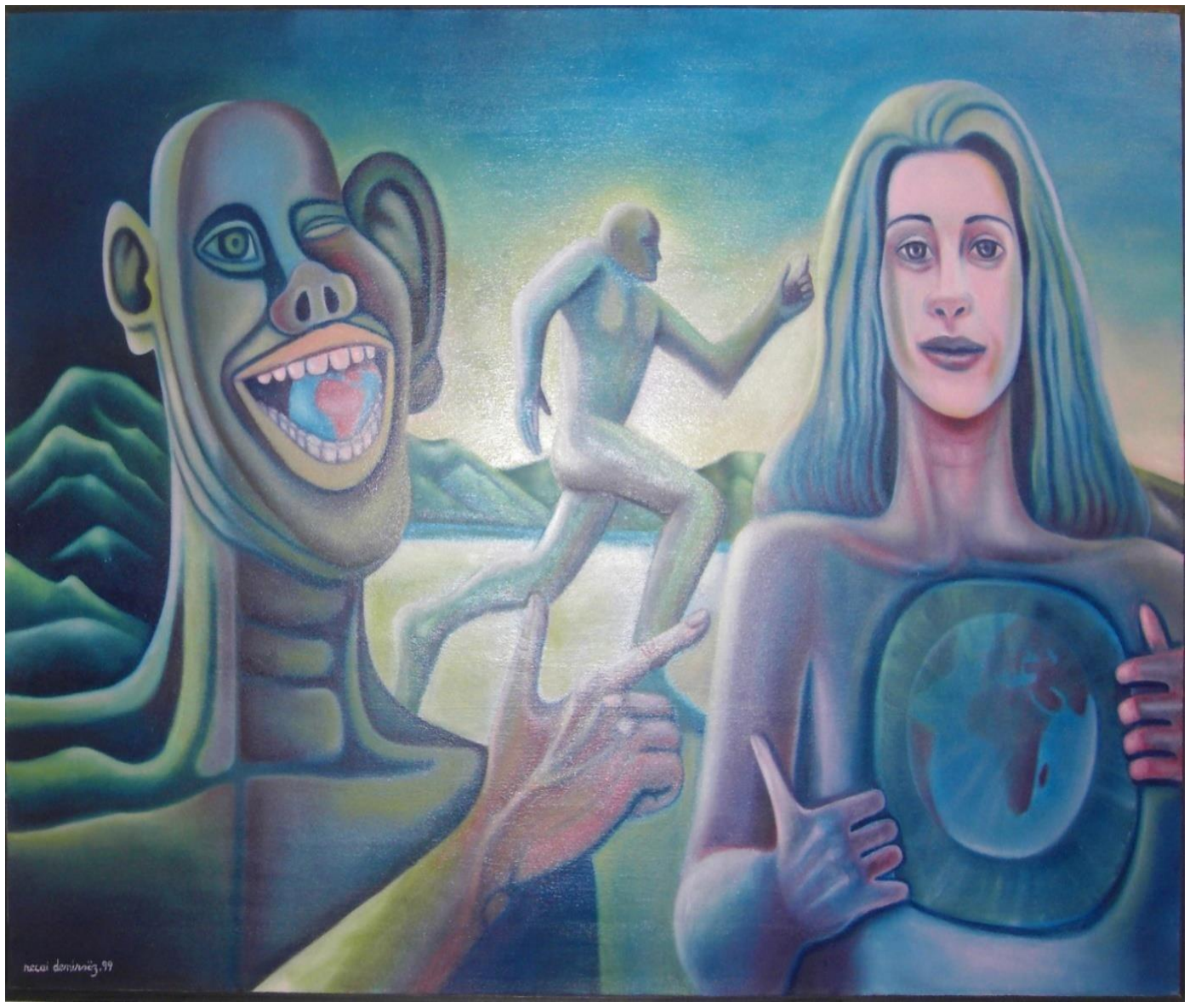

Resim 7

Recai Demirsöz'ün 1999 yılında yaptığı 3 figürlü başka bir çalışması (resim 7) yine toplumsal sorunlara değinmektedir. Tablo'nun solunda bulunan zenci erkek figürü ağzında dünyayı tutmaktadır, dünyayı yemek üzere gibidir, gözünün birisini kapatmış ve gülümsemektedir. Kulağının birisi olduğundan büyük bir diğeri ise figüre göre normal boyuttadır. Eliyle kadın figürünü işaret etmektedir sanki dalga geçer bir ifadesi vardır. Figürün boynundan devam eden derin oyuklar ve çıkıntılar fonda da devam ettirilmiştir. Figür zeminle birleştirmek isteniyor gibi bir izlenim uyanmaktadır. Sağ bölümde bulunan kadın figürü göğsünün içinde ya da kalbinde dünyayı barındırmaktadır. Sanatçı, erkek figürünü dünyayı yok eden, kadın figürünü ise dünyayı var eden şeklinde nitelemektedir, resmin arka planında koşan erkek figürü ise akıp giden zamanı nitelemektedir. Ressamın bu figürde anatomik araştırma içine girmiş olduğu gözlenmektedir, Anatomi eğitimi almadığı gerçeğinin farkındalığı ile belli hataları bulunduğu fark edilse de kendi naifliği içinde ilgi çekici bir figür olduğu söylenebilir. Resmin fonunda yer alan mekân genellikle sürrealist resimlerde gördüğümüz çölü andıran uçsuz bir yüzeydir. Ressam bu çalışmasında erkeklerin dünyayı yok eden kararlarını eleştirirken kadına anaç bir rol vermiş ve dünyayı kalbinde barındıran ve koruyan bir simge olarak kullanmıştır. 


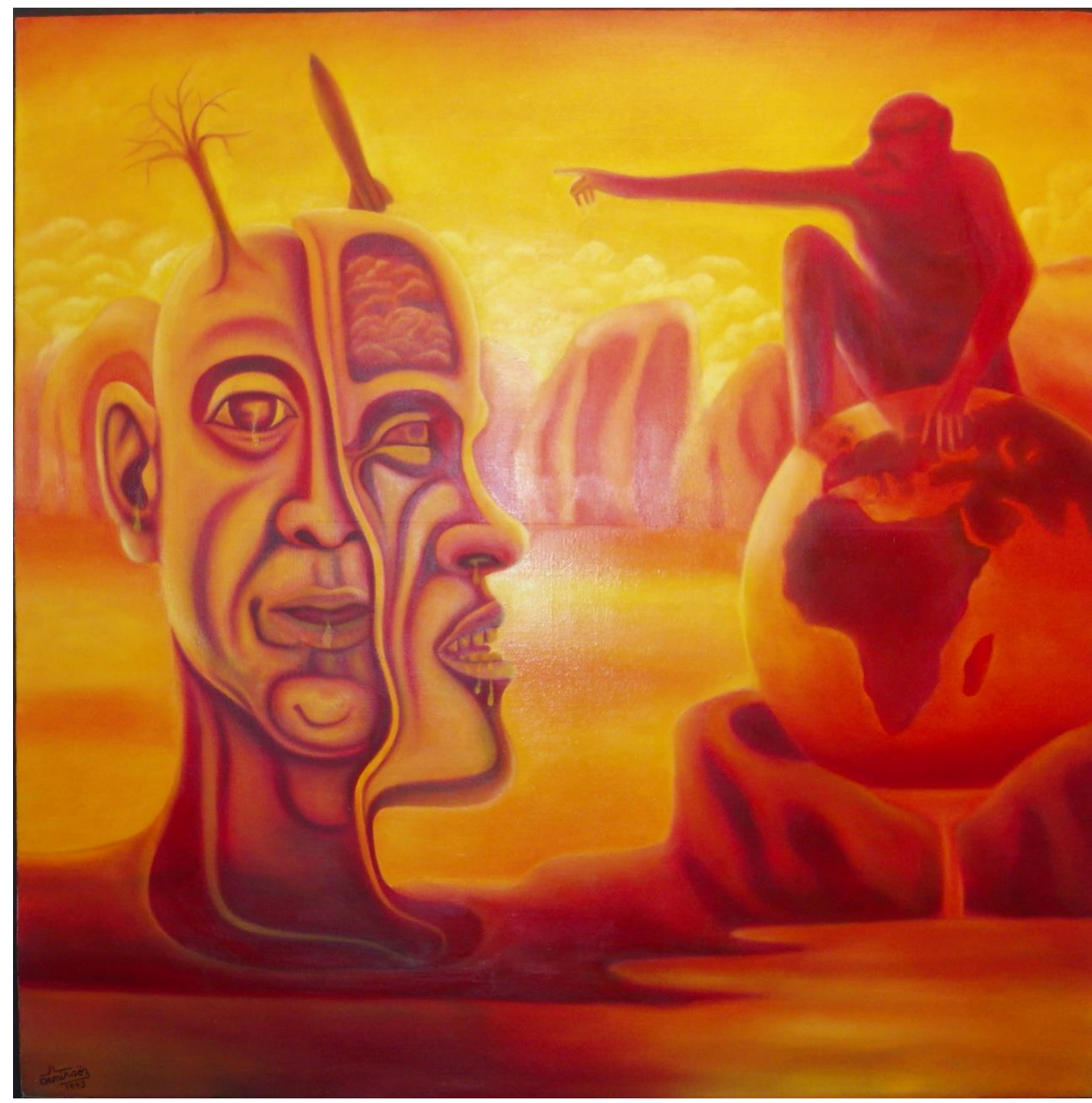

Resim 8

Sanatçının evrensel bakış açısını gösteren bir diğer çalışması da (Resim 8) 1993 yılında yapılmıştır. Bu çalışma da diğer çalışmalardan farklı olarak sıcak renklerin hâkimiyeti dikkati çekmektedir. Çalışmanın merkezinde sol bölümde iki başlı bir büst bulunur, bu başlardan birisi normal bakışlı hatta duygusal diyebileceğimiz bir ifade ile bizlere bakmaktadır. Gözlerinden kulaklarından ve ağzından su damladığını görürüz, bu başın üstünde bir ağaç bulunmaktadır, yalnızca dalları olan bu ağacın kuruduğu izlenimi oluşmaktadır. Sağ bölümde ise bize yan duran başın sinirli ve gergin olduğun hissetmekteyiz, hırçın ve kavgacı hali dikkat çekmektedir, bu başın da ağzından, burnundan su damladığını fark ederiz, fakat yine farklı olarak bu başın üstünde nükleer bomba bulunmaktadır, savaşı ve şiddeti niteler gibidir. Tablonun sağ bölümünde lav akan toprak bir sığınak içinde dünya ve üzerinde bir maymun bulunmaktadır, maymun eliyle bombayı işaret etmektedir. İnsanlığın vahşetini işaret eder gibidir, tablo da bulunan Sıcak renkler nedeni ile savaşın sıcaklığını ve yıkımı hisseder gibiyiz, kompozisyonun mekânı yine geniş ve derin bir yüzeydir çölü 
çağrıştırmaktadır. Bu çalışma da diğer çalışmalar gibi sürrealist eğilimleri göstermektedir.

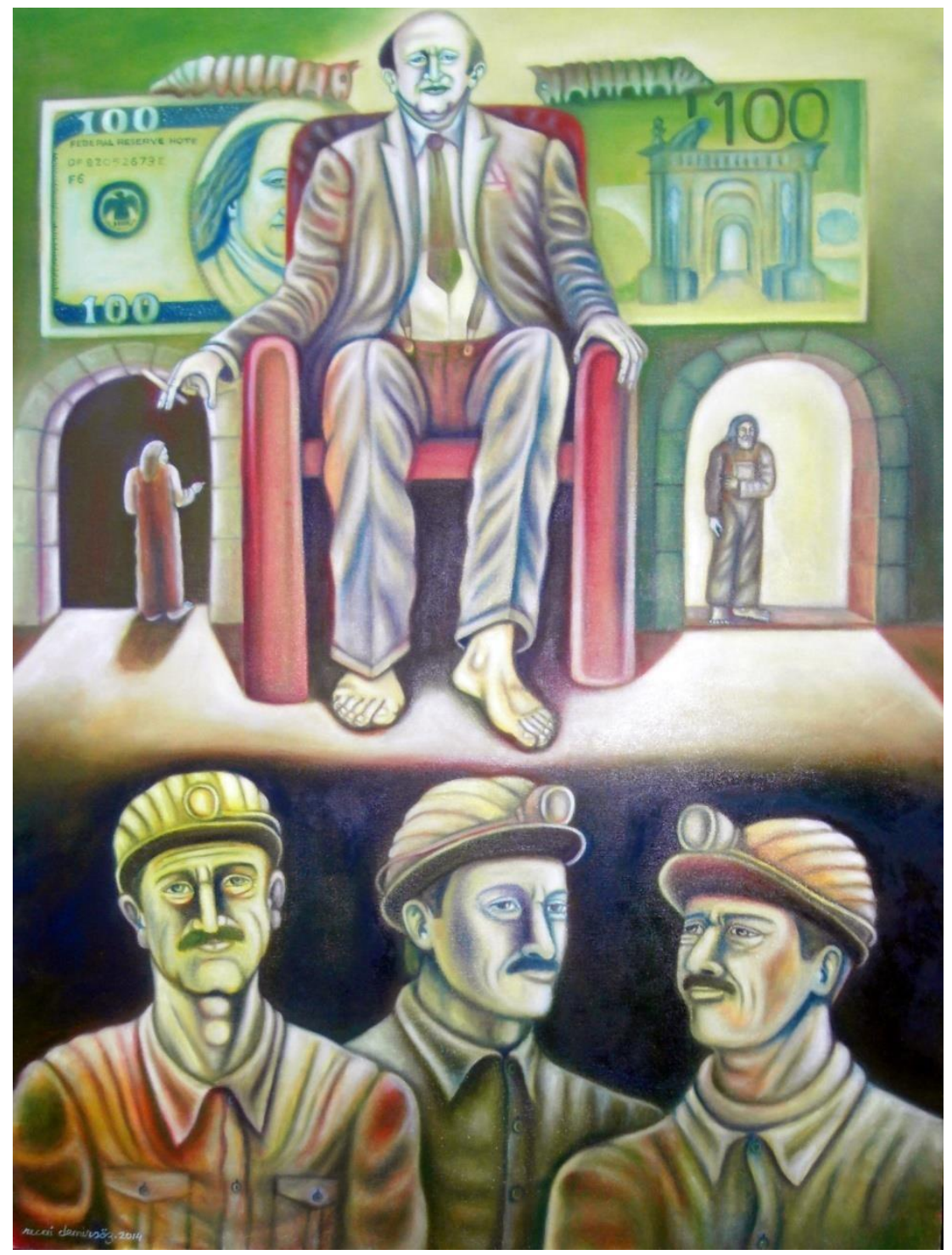

Resim 9

Recai Demirsöz, 2014 yılında 4 resim çalışması yapmıştır bunlardan bir tanesi olan Resim 9' da Soma faciasını anlatan sanatçının bu kez ülkesinde yaşanan bir sosyal soruna temasıdır. Tablo iki bölümden oluşmakla birlikte kompozisyon olarak birbirini tamamlamaktadır. Tablonun üst kısmında merkezde kırmızı bir koltukta takım elbiseli, elinde sigarası ile yalın ayak oturan patron diyebileceğimiz erkek figürü oturmaktadır. Figürün arkasında 100 dolar bulunmaktadır, paranın üstünde parayı yemek üzere olan tırtılları görmekteyiz, ressam burada yabancı sermaye ile kazanılan haksız paraların zaman içinde yenip tükeneceğinden bahseder gibidir. Koltuğun iki tarafında yer alan filozof olduğunu öğrendiğimiz iki figürü görmekteyiz bunlardan birisi karanlığa doğru ilerlerken birisi ise aydınlıktan gelmektedir, ressam burada felsefenin iki yönünden bahsetmek istediğini belirtir ve felsefenin öldüğünden şikâyet eder. Altta 
bulunan 3 figür ise madencilere işaret etmektedir, üstlerinde oynanan oyunlardan habersiz madenciler, karanlıklar içindedirler. Bu çalışmada da ressamın resimlerinde ağırlıklı olarak gördüğümüz soğuk renklerin hâkimiyeti dikkati çekmektedir.

\section{Sonuç}

Recai Demirsöz, yaşadığı imkânsızlıkların da etkisi ile önceki yıllara oranla daha az resim yapmaktadır, fakat resim yaptığı zaman hayat bulduğu gerçeğini de vurgulamaktadır. Resme başladıkça heyecanının arttı̆̆ını resim bittikçe ise kendisinin de tükendiğini anlatır. 30 yıldır resim yapmaktadır ve bu geçen yıllarının değerli olduğunu, bir karede anlatılamayacağını söyler, resimlerinin satılması gibi bir kaygı yaşamamaktadır ki hiç resim satmamıştır da. Hediye ettiği resimleri olmuştur zaman zaman ama resim satmak onun için hiçbir zaman birincil amaç olmamıştır.

Ressam, sanat eğitimi almadığı için Naif ressam tanımlamasına girebilir, fakat çalışmalarındaki üsluba baktığımızda naif resim özelliklerinin yanında farklılıklar da bulunmaktadır. Ressamın çalışmalarında tam olarak çocuksu bir saflık bulamayız, çoğu kez anatomik çözümlemelerde ustalık fark edilir fakat, her resminde aynı zamanda desen eğitimi almamasından kaynaklanan belli anatomik bozukluklar da göze çarpar. Her iki durumu da tablolarında net olarak görebiliriz. Renk kullanımında Naiflerin çoğunun aksine soğuk renkleri tercih eder, konuları sosyal konulardır, kadınları çok kullanır ve kadın dostudur, kadınların acılarına ve çile çekmiş kadınların duygularına yakın olma eğilimindedir, konu açısından da Naif ressamlardan bir bakıma ayrılmaktadır. Doğadan, köy hayatından ya da şehir hayatından izlenimleri pek göremeyiz, ressam, daha çok konularını dünyayı etkileyen problemlerden almaktadir.

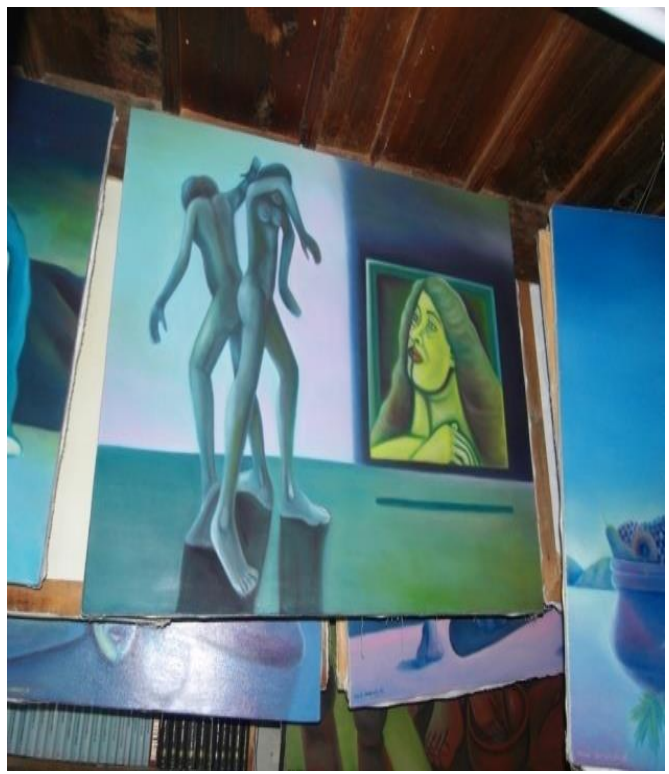

Resim 10

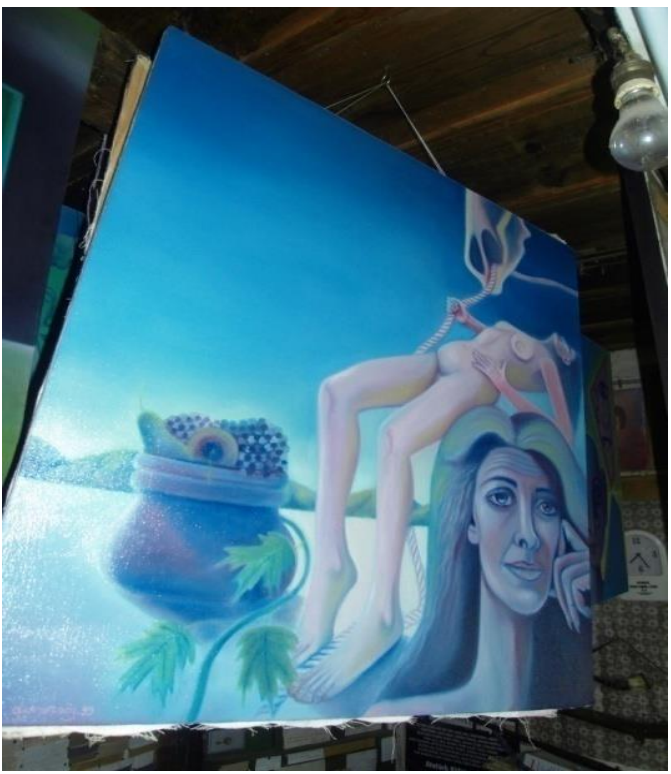

Resim 11 
Recai Demirsöz'ün tarzını tam olarak niteleyememekle birlikte sürrealizme yakın olduğu söylenebilir, resimlerinde mekân olarak genellikle çöl ya da geniş alanları tercih eder, sonsuz gidişi çağrıştıran bu tür arka planlar Sürrealistler tarafından kullanılmıştır, bunun belirgin bir örneğini resim 12'de Salvador Dali'nin ünlü saat çalışmasından esinlenmede görülebilmektedir. Ressam kendisini öncelikle Realist olarak nitelemektedir ve dünyanın yok edilişini anlatmak biricik amacıdır.

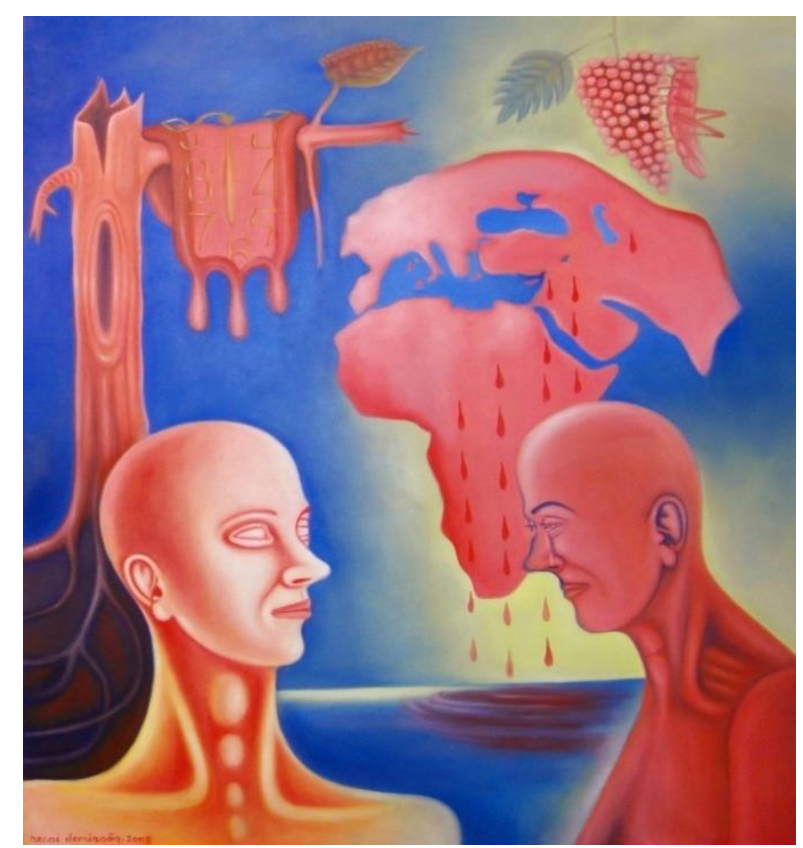

Resim 12

Çalışmalarında kendisine özgü bazı teknikler fark edilir, tuval yüzeyleri bir kâğıt gibi pürüzsüzdür ve resimleri belli bir parlaklıktadır. Ressama bu konu ile ilgili sorularımızda bu tarzını yıllar içinde kendisinin bulduğunu ve fırçanın hep tek tarafı ile çalıştığını anlatır.

1984 'ten bu güne kadar 10 sergi açmıştır, bu sergiler Safranbolu ve Karabük'te yapılmıştır ve devlet desteği/davet ile gerçekleşmiştir. Şu sıralar ise ressam sergi açmayı düşünmediğini anlatır fakat farklı bir şehirde sergi açma özlemi de bulunmaktadır. Çok yönlü bir beceriye sahip olan Recai Demirsöz tuvallerini, çerçeveleri, hatta şövalelerini de kendisi yapmıştır.

Ressam bugün hala köyünde yaşamını sürdürmektedir, ulaşım gibi bazı zorluklarla mücadele eden Recai Demirsöz, Sanat Galerisinin varlığını sürdürmeye çalışmaktadır. Zaman zaman kendisini ziyarete gelen sanatseverler ve Galerinin bakımı için yardımcı olmaya çalışan kent içinden kişilerin olduğunu anlatır. Yapılan bu ziyaretler arasında basın-yayın organları da bulunmaktadır. TRT kendisi hakkında bir program yapmıştır, ayrıca hakkında yazılan gazete haberleri bulunmaktadır. Bunun dışında Karabük Üniversitesi Safranbolu Meslek Yüksek Okulu öğrencileri tarafından kısa belgesel çekilmiş ve bu belgesel ödül almıştır. İstanbul Modern, Beşiktaş Kültür Merkezi gibi sanat dünyası içinde oldukça etkili Kurumların temsilcileri tarafından da 
ziyaret edilmiş sergi davetine bulunulmuştur fakat, ressam eserlerine zarar gelmesinden çekindiği için bu tür organizasyonlardan kaçınmaktadır. Eserleri için tam bir güvenlik istemektedir.

"Tozpembe değilim" diyor Recai Demirsöz, bu bağlamda çalışmaları hissettiklerinin bir yorumu olarak karşımıza çıkmaktadır. Resmi meşhur olmak gibi bir kaygıyla yapmamaktadır, zengin olmak gibi istekleri yoktur, sefalet içinde de ölebileceğini söyler, çünkü ressamın hafızasında tüm acı çeken sanatçıların resimleri vardır, onların yaşamlarına saygılıdır, kendi yaşantısına da saygı duyulmasını beklemektedir.

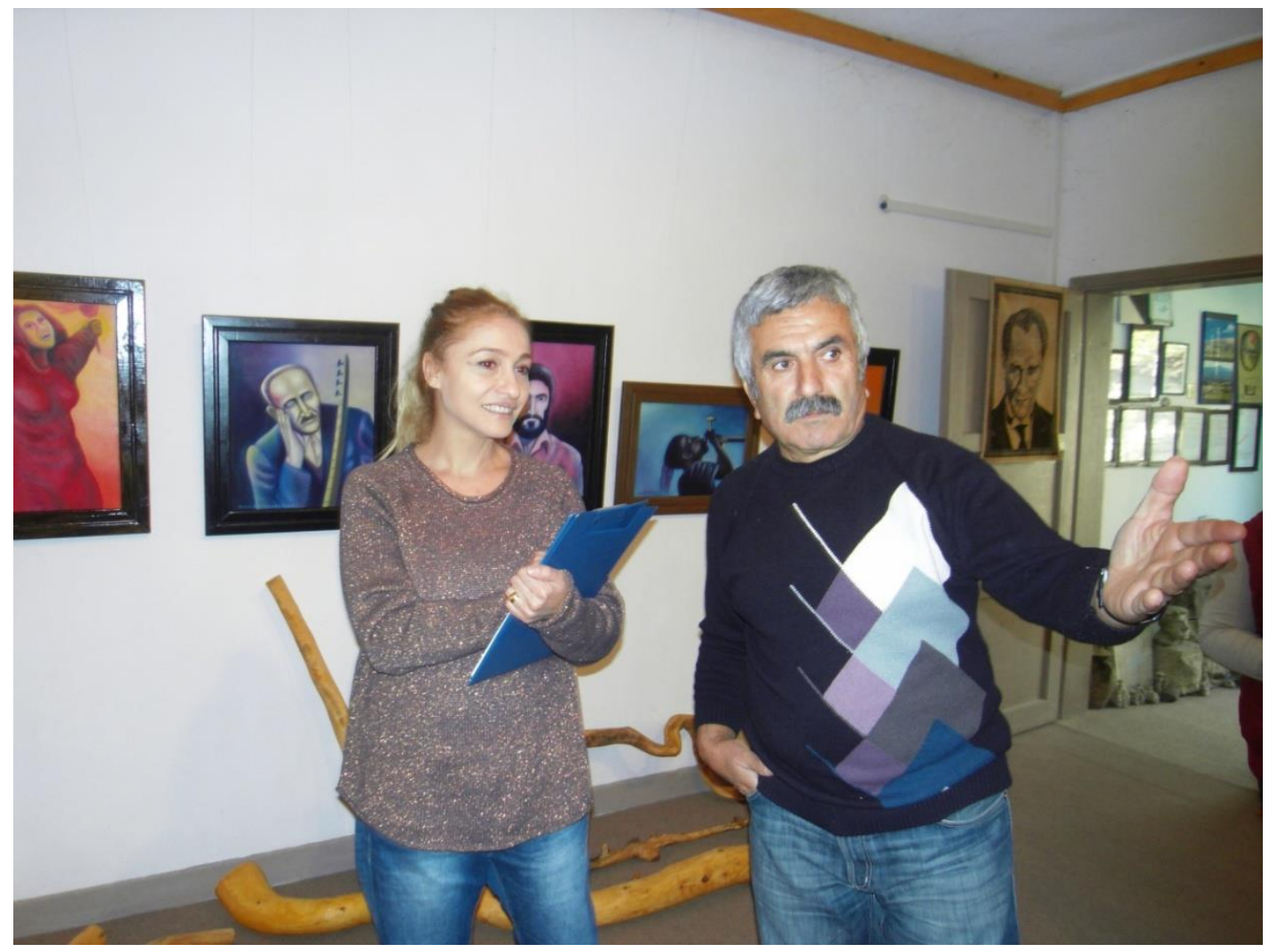

\section{Kaynakça}

Aksoy, F. (1990). Naif Sanat ve Türk Naifleri. İstanbul: Ak yayınları.

Antmen, A. (2010). 20. Yüzyıl Batı Sanatında Akımlar. İstanbul: Sel Yayınları

Elvan, N. (2001). Türk Plastik Sanatlarında Otodidakt ve Naif Sanat Çocuk Yaratıcılık (19501960), Yayınlanmamış Yüksek Lisans Tezi, Ankara: Hacettepe Üniversitesi Sosyal Bilimler Enstitüsü

Franck, D. (2009). Bohemler. İstanbul: Sel Yayıncıllk

Little, S. (2013). İzmler sanatı Anlamak. İstanbul: Yem Yayın

Lynton, R. (1991). Modern Sanatın Öyküsü. İstanbul: Remzi Kitapevi. 
Manukyan, A.Ş. (1999). "Naif Resim". Cumhuriyet'in Renkleri, Biçimleri. İstanbul: Tarih Vakfı Yayınları.

Sözen M.,Tanyeli, U. (2012). Sanat Kavram ve Terimleri Sözlüğ̈̈. İstanbul: Remzi Kitapevi.

Tansuğ, S. (1995). Türk Resminde Yeni Dönem. İstanbul: Remzi Kitapevi

Tarhan. U. (2013). Otodidakt (Autodidact), Kaynak: Martı Dergisi: http://www.martidergisi.com/otodidakt-autodidact/ adresinden erişildi

Yasayaman, Z. (2008) "Aksoy'un Ardından" Kaynak: Milliyet Gazetesi.http://v3.arkitera.com/arsgratiaartis.php?action=displayNewsItem\&ID=24648 adresinden erişildi. 